\title{
INTRODUCTION: ITALY BETWEEN \\ EUROPEANIZATION AND DOMESTIC POLITICS
}

\author{
Sergio Fabbrini and Vincent Della Sala
}

There has been a continuous discussion since the second half of the 1980s on the transformation of the most important political, institutional, and social structures within states, especially European states. ${ }^{1}$ If a polity is defined as the various spheres-political, institutional and social - that constitute states, then it may be argued that changes on a European and global scale, along with transformations that affect the sub-national level of government, have given rise to a series of structural constraints and factors that shape political and social life well beyond the borders of the national state. It is a discussion that has not spared Italy, especially given the scale of change experienced in the 1990s. This is not to say that internal factors no longer exert an element of agency. Rather, endogenous forces need to be placed within a broader context. The links between exogenous influences and endogenous dynamics might help explain the continuity and change of the structures of various national polities. The events of 2003, presented in the chapters that follow, provide ample material in this respect.

The year 2003 was marked by the search for new parameters within Italian politics; that is, the attempt by the government and its parliamentary majority to introduce new orientations in both domestic and foreign policy and new practices in the framing and substance 
of public policy (as in the cases of social and labor policy), and therefore to introduce new power relations between representatives of social groups, in particular, trade unions and employer associations. In foreign policy, the government tried to radically change the country's position from a decidedly pro-European stance to an Atlanticist one, with the vision of Europe shifting from the traditional Italian "supranational" view to a more intergovernmental position. In domestic politics, along with labor policy, there was an attempt to change parts of the welfare state that have been a point of weakness in the country's system of social security. Moreover, there was an effort to carry out these changes to labor and social policy by shunning social concertation; that is, there was an attempt to alter the institutional and regulatory mechanisms that have governed relations between social partners since 1993. The process of shifting the parameters of politics included the country's political parties. Within the government and parliamentary majority, the deputy prime minister and head of AN, Gianfranco Fini, sought to break his party free of its xenophobic and authoritarian past. Within the center-left, European Commission President Romano Prodi proposed a "single list" for the 2004 European Parliament elections that would overcome the opposition's internal divisions.

The government's attempts to change the parameters of Italian politics were not particularly successful, partly because of their often contradictory nature. In some cases, the government was forced to "retreat": in others, the resistance generated to the attempted change led to confused and improvised responses. Moreover, this complex process of pressure for change and resistance requires a more sophisticated reading of Italian democracy than that normally offered outside of Italy (and not just in journalistic accounts). ${ }^{2}$ Italian democracy is neither immutable and frozen nor in a state of permanent and chaotic change, as it is often described. The events of 2003 demonstrate that the Italian polity has its epicenters and equilibrium points, just as one would expect to find in any consolidated democracy. Despite being subjected to tremendous pressure, these epicenters were much more resistant to change than is normally acknowledged (by both actors and observers). The important point is that this resistance was due in part to the integration of the Italian polity into the general system of governance in the European Union (EU), that is, its Europeanization. If Europeanization is used as a heuristic tool for empirical research, then it becomes clear that the various constitutive elements of the Italian polity are integrated to such an extent with those of the EU that any attempt to change the former will lead to some form of reaction by the latter. The use of the concept of Europeanization, then, seems 
to suggest a qualitative change in the process of European integration (more precisely, after the Maastricht Treaty in 1992). It is increasingly difficult to establish the boundaries between the national and EU arenas, as Europeanization implies a high level of integration that has penetrated institutional structures, operating rules, public policy networks, cognitive paradigms, and national and European ways of thinking. Clearly, the Europeanization process is not uniform. Some Italian institutions and policies are much more integrated with those in Europe, in the same way that some actors are more Europeanized than others. We also cannot assume that the Europeanization process is unidirectional; it operates on the domestic and European fronts. Not only does the latter influence the former, but the opposite holds true as well. For our discussion, we will take the European arena as "independent" so that we can concentrate attention on the domestic level, where the outcomes (institutions, policy, values) constitute our dependent variables.

It became apparent during the course of 2003 that the government faced great difficulty in trying to institutionalize the new parameters in the modalities and substance of public policy-making. This was due to a number of different factors, from the opposition that was generated within the country to reactions that came from Europe. The key point is that when these forms of resistance coalesced, the center-right government was forced to reassess its strategy, in some cases gradually, in others much more suddenly. Therefore, one of the ways to interpret the events of 2003 is to understand the relationship between Europeanization and internal dynamics. This will help to explain the difficulty in trying to move the baricenter of the Italian polity, even if the shift was sought by the largest government majority since 1993 . The Europeanization of politics, institutions, and society was not only a constraint on internal dynamics but also an opportunity for their development when actors were able to exploit it. This introduction will examine the events from both perspectives, distinguishing between European influences and internal dynamics. In this way, the different forms of pressures that were exerted and the effects that were created when they came together will be highlighted.

\section{The Europeanization of the Italian Polity}

The events of 2003 confirmed a process of Europeanization that had been underway for at least a decade, but also introduced a few notable novel features. The most significant of these was the Europeanization of the party system, which had hitherto proven to be the 
most resistant to supranational dynamics. If Europeanization had thus far had an impact on institutions and (some) Italian policies, then in 2003 it seems that the process of Europeanization extended to the system of political forces. ${ }^{3}$ On the center-left, it was Europe (or more precisely, the need to prepare "properly" for the June 2004 elections to the European Parliament) that provided the opportunity to promote a new political actor (The Party of Reformers). ${ }^{4}$ The European impulse was used by specific actors to initiate a process of party reconstruction that had met great resistance in the past within the center-left. The decision to present a "single list" of the major parties of the center-left for the European parliamentary elections in 2004 also emerged from the dynamics of internal politics, as Michele Salvati notes in this volume. Nonetheless, it is reasonable to assert that Europe represented a not insignificant opportunity for those who wanted to realize the single list, particularly because the elections could be used as a testing ground for the proposal without having immediate (and risky) national implications. In addition, the major parties of the center-left cannot continue to belong to different European parties; for instance, the Popolari, or centrists, in the center-left belong to the European Popular Party, which includes MEPs from Forza Italia. Finally, the Italian party system remains the only one among the major European states without a large party of the left or the center-left. Therefore, without the European wind, it is unlikely that the sails of Romano Prodi's single list would have swelled and guided the boat through the stormy inter-party waters. Most probably, without the European justification, the sailboat would have never left the port, frozen in by debates between the leaders of various parts of the center-left. Perhaps only the girotondini (popular protesters outside of the formal political parties) might have provided the inspiration to set in motion some kind of unified list. Europe provided a formidable opportunity for those seeking to neutralize internal vetoes, making possible what did not seem realizable previously. Moreover, if the list was successful, it would have noticeable effects on European politics as well. The emergence in Italy of a large progressive aggregation, electorally comparable although distinct because of its multiple identities to those in other parts of Europe, could possibly change the structure of European reformism. It most likely would favor the evolution from radical socialist roots to a broad church party of the center-left (as is the case with American political parties).

Europeanization has also made an impression on the center-right, and this will likely be felt even more as an effect of competition from a possible single list of the center-left. An indication of what is to come might be found, as Mark Donovan shows in his chapter, from 
the conflicts that exploded within the majority coalition (and the government itself). The question of granting the vote to immigrants (which saw a fiery clash between the leader of the National Alliance and the Northern League) was tied to the European debate. In recognizing the right of immigrants to vote in the localities in which they reside, the leader of the National Alliance decidedly distanced himself from the constellation of European xenophobic parties with which his own party continues to be associated. It is not a coincidence that this same constellation remains at the margins of European decision-making. The radical decision by Gianfranco Fini, leader of the National Alliance, to dissociate himself from the fascist regime could also be explained by the need to establish personal international credibility. In addition, Fini softened his initial Euro-skeptic position in favor of support for proposals to create a political identity for the EU within the European Convention that drafted a constitution for the EU. Only by becoming a conservative leader recognized by other European conservative leaders-and thereby earning a legitimate claim to enter the European Popular Party on its own or as part of a center-right coalition-could Fini think of proposing himself as the potential leader of a future centerright government. It is still too early to assess the impact of Fini's choices. In order to understand them, one must take into account his need to broaden his constituency and seek credibility beyond his traditional domestic electorate, as well as in European terms.

Europe also defined the framework within which the principal decisions and choices were made on institutional questions. More precisely, it represented the background against which the possibilities of success of the new parameters were set. It was the imminence of the Italian presidency of the EU that led the Italian Parliament to approve the Maccanico-Schifani legislative proposal on granting immunity to holders of important office and that led the president of the Republic to sign it into law. It was a decision that had notable constitutional significance, as it rendered some citizens-those occupying the five most important offices-more equal than others before the law. Notwithstanding its controversial nature, it was enacted in response to a sort of “European” emergency. Italy's European responsibilities, it was said, prevented the possibility of going forward with weak governments (as had been the case in the past during the First Republic) or with delegitimized governments (as had been the case with the first Berlusconi government in April-December 1994). Europe presented an opportunity to secure the legitimation of the government, as well as that of the prime minister himself, and, therefore, an opportunity to alter the balance of power between the executive and the judiciary to the benefit of the former. 
As Francesc Morata illustrates in his chapter, it was the Italian presidency of the EU that defined a large part of the public debate and the parliamentary agenda in the second half of 2003. From Berlusconi's first address to the European Parliament in July (which risked creating a serious diplomatic crisis between Italy and Germany) to his speech to the association of European industrialists (which reopened divisions within the government between Europeanists and anti-Europeanists), Italian politics was dominated by the reaction of European states to positions assumed by the government and Prime Minister Berlusconi. In particular, in foreign policy the prime minister and his majority had to recognize that there was a European equilibrium that was not easily modified by factors entirely rooted at the domestic level. Three examples can illustrate this. The first deals with relations with Russia. Italy was isolated first in proposing an eastern enlargement of the EU that included Russia and then in absolving the domestic policies of Russian President Vladimir Putin, especially those in Chechnya and those with respect to media ownership and freedom of the press. The second example was the European position on the Middle East crisis. Italy was alone in assigning exclusive responsibility to the Palestinian Authority for the stalled peace talks. This led to a refusal by Berlusconi to meet with Yassir Arafat on a visit to Palestine in preparation for Italy's presidency of the EU. Italy also was the only EU state to endorse the security policies of the Sharon government. The third example was with respect to European defense policy. Italy was again isolated with its proAtlanticist position, especially in its assumption that NATO was the only organization upon which the defense of the Continent could be secured. In a tripartite meeting in Berlin in mid-October, the British government reached an agreement with the French and German governments on the construction of a European defense component, albeit within the broader umbrella of the Atlantic alliance. This left Italy, along with the Spanish government, alone in criticizing positions taken by the Franco-German axis.

It is not surprising, then, that in the final round of negotiations of the Intergovernmental Conference on the European Constitution in December, Italy abandoned its Euro-skeptic and pro-Atlanticist allies (Spain, Poland, and Great Britain) to edge closer to the more European positions of France and Germany. ${ }^{5}$ These positions were so heavily criticized by the very same Italian government two years earlier that they led to the resignation of Renato Ruggiero, the foreign affairs minister at the time. Even though the Italian prime minister became one of the closest European friends of George W. Bush, this was not enough to have him change Italy's pro-European policy. The 
efforts made by Berlusconi and Defense Minister Antonio Martino to have Italy assume a more pro-Atlanticist and Euro-skeptic position, then, did not lead to any significant results. They met resistance from Europe, from domestic opposition forces, and from within the governing coalition itself, as well as the president of the Republic. As a result, support for the United States and the military intervention in Iraq, as Osvaldo Croci points out, turned out to be more "moral" than political and practical (even if that support did have dramatic consequences for the soldiers in the field, especially with the Nassiriya bombing in November). Also, the distancing from the Franco-German axis did not result in an alternative alliance with Spain and Britain. Lastly, criticism of the EU was replaced with its defense in an effort to provide Europe with a constitution during the Italian presidency.

The European context was also present in the discussion on the reform of the structures and mechanisms of the Italian labor market. From a range of proponents including not just trade unionists but also the presidents of the republic and the two Chambers of Parliament, there were numerous calls to preserve Italy's version of the "European social model." Despite the government's electoral promises to make labor markets highly flexible, it had to soften its neo-liberal reforms, much to the chagrin of the employers' association, Confindustria. As Lucio Baccaro and Marco Simoni reveal here, the reform of labor markets was finally presented as an opportunity to "modernize" the Italian economy without radically altering an equilibrium that was generally considered in Continental Europe as based on the welfare state. The debate on the reform of the research agencies, as Massimiano Bucchi and Federico Neresini demonstrate in their chapter, also was influenced by Europe, as well as by the broader process of the globalization of the economy and scientific knowledge.

The reform of the RAI, and broadcasting in general, was first thrust onto the political and parliamentary agenda with a degree of urgency by outside pressures. ${ }^{6}$ The Economist's 2001 election campaign cover story titled "Why Berlusconi Is Unfit to Govern Italy" remained a thorn in the government's side, especially since it highlighted Berlusconi's conflict of interest and his possible control of the entire broadcasting system. Clearly, internal actors were central to the reform of the RAI. However, the issue continued to be seen by European public opinion as a European issue, if for no other reason than the fear that the "Italian model" could become exportable to the rest of Europe. This was the basis of a motion criticizing the Italian media system by the European Parliament in October 2003; moreover, it was backed by the Popular Party, which included Forza Italia. European pressure continued to increase in the second half of the year, culminating in 
another Economist cover story, this time with the title "Why Berlusconi Is Unfit to Represent Europe.” The legislative solution to the Italian broadcasting system, the so-called Gasparri law, is destined to come up against European rules. Approved by Parliament on 3 December, it consolidated the duopoly of the system, as well as opening up space for an expansion of the private oligopolist, the prime minister's own Mediaset. As legal expert Guido Rossi pointed out, the Gasparri law does not comply with European law in that "there are precise limits in European anti-trust legislation that prevent the creation of dominant positions" within single member states. ${ }^{7}$

The issue of the financial crises of the football clubs, examined by Nicola Porro and Pippo Russo, provides further evidence of the difficulty in searching for national solutions for even the most national of problems. The legislative and policy responses to avoid financial insolvency for the major football clubs provide insight into the particular orientation of the center-right government. However, what needs to be emphasized here is that those solutions were soundly criticized by the European Commission, more specifically, by the Directorate General for Competition led by Mario Monti. Beyond the rhetoric in reply to the European Commission, the fact remains that Italian football has had to deal with its Europeanization, something that has been going on for some time. For instance, the "Bosman decision" of 1995, which liberalized the free movement of footballers throughout the EU, subjected the most popular of national sports to the rules of the single market. The financial crisis of the major Italian clubs is rooted in the incapacity of their managers and political leaders to understand the needs of an industry that now operates on a European and increasingly global scale. The old reflex of having the state intervene to bail out national firms has run into EU rules concerned with ensuring that competition exists even among European football clubs.

Even at the societal level, the most important changes need to be understood within a context that goes beyond the national. As Donatella della Porta and Mario Diani demonstrate in their chapter, the most visible pacifist movement in the history of post-World War II Italy had a distant connection to matters that were strictly national and was an element of a broader international movement against the Iraq war and globalization. It drew its identity from responses to the challenges of international affairs more than domestic politics. AntiBerlusconi sentiments played a secondary role in mobilizing Italian pacifism, whose objective remained to challenge the unilateral decision by the United States to intervene in Iraq as well as the divisions among the EU member states. The unprecedented pro-American position of the Italian government allowed for the disparate elements 
mobilizing against the war-from the most strident opponents of the United States to the moderate critics of the war-to find unity in opposing the war. However, it is important to note that the pacifist movement did not transform itself into a simple anti-government movement, thus making it harder for the numerous opposition forces to use the anti-war movement for domestic objectives. In some respects, even the death of the honorary president of Fiat, Giovanni Agnelli, did not have, as Gaspare Nevola shows here, exclusively domestic implications. Agnelli had come to symbolize an Italy that was internationally accepted. Italy seemed to recognize itself in those who gave it recognition internationally, as probably occurred after the dramatic death of Italian military forces in Nassiriya in November. The international significance given by Italian public opinion to these moments of mourning and grief may be understood as the other side of the same coin that reflects international criticism of the Italian prime minister. Both sides speak of the importance of the international scene on domestic politics.

An important paradox that is worth reflecting upon emerged in Italian politics in 2003. Why was a government majority, with the largest parliamentary majority in the country's history, progressively transformed into a politically uncertain and weak coalition? In addition to the obvious domestic factors, which are discussed below, this section has highlighted the external reasons. These are primarily related to the difficulties of the governing coalition in its attempt to introduce new parameters to domestic politics within the context of European integration. Europe, then, can be seen as an explanatory factor in the success or lack of it in domestic politics.

\section{Factors Internal to the Italian Polity}

While Europe may have exercised important constraints on the Italian polity, there were just as many significant domestic pressures. ${ }^{8}$ This domestic level is articulated on many different and independent levels. For instance, as the chapter by Guido Legnante demonstrates, the traditional view that local and regional elections were simply an extension of the dynamics of national electoral and party politics is no longer a given. Rather, features such as the direct election of mayors and the autonomy of particular areas, including the autonomous provinces of Trento and Bolzano, have given a new meaning to the sub-national levels. Moreover, actors and institutions at this level now have new interlocutors in Europe and counterparts across national borders. The challenge is understanding the ways in which 
structural constraints at the European level must also interact with abiding elements of local and regional politics, and how this can create new opportunities for political actors.

The enduring tensions of Italian politics are readily available within the dynamics of the center-left and center-right. This is most apparent within the Italian left. As the chapter by Michele Salvati demonstrates, the perennial conflict between moderates and "radicals" (which may be traced back to the industrialization of the late nineteenth century) persists, even if in a somewhat modified form. This tension has been heightened by differences over how to address questions that emerged in a post-Cold War international order and with economic interdependence. The anti-American reflex is sometimes confused with opposition to globalization, but in whatever form, it is a contentious issue for the left. On top of this division within the left, there can be layered a new cleavage around the question of how to deal with Berlusconi. This axis runs from those who see him as simply a political adversary and are willing to engage in an attempt at some form of constructive dialogue to those who see him as a political enemy and are more intransigent with respect to relations with the government. A form of two-by-two table may be imagined in which the many forces of the left can be mapped out. This complexity shows no mercy with those who try to manage it, as the case of Sergio Cofferati attests. In the space of less than a year, he seemed to have gone from rising star capable of bringing new forces into the traditional left to yet another victim of the struggle for space on the left of the spectrum. As Salvati points out, it was largely in the vacuum created by the Cofferati eclipse that Romano Prodi launched his appeal for a single list for the left in the 2004 European elections. It remains to be seen whether this decidedly European attempt can hold together the four quadrants of the Italian left.

Similar divisions over broader visions and tactics for dealing with the Berlusconi government seem to divide Italian trade unions. As the chapter by Baccaro and Simoni demonstrates, trade union unity in the last decade has vacillated according to the issue and the degree of willingness of CISL and UIL to work with the center-right government. Divisions burst into the open in 2001 when the two confederations decided to negotiate with the government. Trade unions are faced with a series of difficult decisions that encompass a range of factors, from the changing nature of work to an aging population. Baccaro and Simoni point out that the decisions being made will reflect particular visions of society. For instance, defending the current labor market regime means possibly ignoring the demands of largely excluded groups, such as youth and women. On the other 
hand, trade unions, as structures, face great challenges in organizing those parts of society that are not in the labor force. These sorts of tensions have become crystallized around issues such as Article 18, whose importance is linked more to political symbolism than to any concrete impact on labor market performance. The government's attempt to change labor markets through a strategy of confrontation with trade unions has led to a restoration of their unity. It has also mobilized institutional forces, including the president of the Republic, that are opposed to a radicalization of social conflict. The government's attempt to redraw the boundaries of economic and social policy could not alter the political equilibrium that has been in place since 1993 and that has seen changes in public policy emerging only from social concertation.

The center-right coalition, as Mark Donovan demonstrates in his chapter, shows just as many fault lines as the left, and these came to the surface in 2003. They reflected not just poor local election results, highlighted by Guido Legnante, but also the ambitions of different parties in the coalition, based on enduring and new epicenters on the right of the political spectrum. It might be argued that there is a twoby-two table here as well, with one axis defined by the liberal-statist spectrum. The second axis reflects new challenges and how to deal with fundamental questions that define the right-order and notions of political community-in an integrated Europe and an increasingly global world. The Italian center-right has challenged conventional wisdom with, on the one hand, the supposedly free market minister of the economy, Giulio Tremonti, railing against the constraints on public spending imposed by the Stability Pact or threatening protectionist measures against Asian competition, and, on the other hand, Deputy Prime Minister Gianfranco Fini, who would be expected to assume positions characteristic of a closed nationalist vision, threatening government stability by promoting the extension of the vote to immigrants and visiting Israel. Recent developments on the right in Italy have only underscored how anomalous it is in comparison to its counterparts elsewhere. There is clearly a lack of vision about how to make sense of a post-Cold War world, one in which national borders have become if not insignificant at least highly porous. Attempts to provide this mental map have only highlighted how elusive it remains. ${ }^{9}$ Right-wing populism becomes an easy reflex, one that can compensate for the lack of a normative and political project to deal with a new world. ${ }^{10}$ We have the strange situation of a governing coalition in which all of the parties feel that patriotism is a good thing in itself, except that some express it on a national basis and others see it in regional terms. These new questions-such as how much space 
should be given to markets in social regulation and what is the basis of belonging-are layered over lingering issues about the historical legacy of not only fascism but also post-war Christian Democracy.

Some of Italy's main cultural institutions and structures-such as the RAI, its intellectual and research centers, and the world of professional football-have also had to face new challenges bound by old constraints. The chapter by Matthew Hibberd illustrates the tension between constraints and opportunities made possible by the introduction of new technologies in telecommunications and television broadcasting. On the one hand, the instrumental use of public television for political purposes has continued, albeit taking on new forms in recent years. On the other hand, hopes for a new pluralist age spawned by new technologies are premature. Both these tensions, that of breaking free from the old constraint of political control and responding to the challenges of new technologies, are only heightened by Italy's irregular structure of media ownership. It is interesting to note how the language and terms of new opportunities are used to justify the continued duopoly in media ownership. It is argued that if Italy wants to withstand the competitive pressures of the new era of broadcasting, it needs to strengthen the old structures. This becomes a useful justification for the Gasparri reform, which further entrenches the Mediaset empire while doing little to create a more autonomous RAI. Its privatization has been presented as an option, but, as Hibberd argues, in the absence of other changes, it is unlikely that privatization would create more opportunities for greater pluralism. One of the consequences of the Italian anomalous duopoly is that it protects the interests of Prime Minister Berlusconi from competitive pressures.

Competitive pressures are also an important part of the story for the future of research and professional football in Italy. As the chapters by Bucchi and Neresini and by Porro and Russo demonstrate, sectors of Italian society that had been able to remain relatively shielded from assessments based on criteria formed outside of Italy now find themselves facing important decisions. In the case of research, Italian policy-makers have had to find ways to address the question of how to ensure a vibrant and healthy research community in an era of shrinking budgets and extremely mobile researchers, who might be attracted to higher salaries and more advanced structures elsewhere. However, decisions must be made within a framework that is governed by rules and norms that in the past have not had to take into account competition. It may seem strange to talk about football as not being governed by norms based on competition, but it is telling that Italian clubs were considered not-for-profit organizations 
until 1996. The various financial and management troubles of Italian football clubs might be understood as the result of not being able to cope with the demands of a multi-billion euro industry that now includes complex ownership structures such as publicly listed companies and new forms of revenue such as pay-per-view television. Moreover, as a result of the Bosman decision, it is football that provides one of the best examples of how even the most quintessential of national pastimes must find ways to deal with the competitive pressures of a single market.

The death of Gianni Agnelli provides an opportunity to examine the ways in which the old and new co-exist in an Italy that looks for opportunities in the contemporary world. As Gaspare Nevola argues, Agnelli defined post-World War II Italy for many, both inside and outside the country. Fiat was the symbol of the post-war transformation of Italy into one of the leading industrialized societies in the world. The company's recent crisis reflected not just upon the fortunes of an industrial giant that perhaps had not kept up with the competition, but upon an entire economic and social model. The national champion model of industrial policy has been surpassed for some time, but this became very apparent in the past year. The combination of European competition rules and international rivals highlighted the extent to which, despite years of state assistance and protection, the Italian car manufacturer had not prepared for the opening of national borders. The eclipse of the industrial model, an essential element of the Italian post-war settlement, was symbolized by Berlusconi's arrival at the Agnelli funeral. The crowd waiting outside the Duomo in Turin contested the entrepreneur-prime minister, arriving late and not in an Italian-made car. The changing of the industrial guard has been anything but smooth or complete.

Finally, the questions about Fiat's future and the possible role General Motors may have in shaping its destiny lead our discussion to the prominent place of the United States in the events of the last year. There was never any doubt that a government led by a prime minister who claimed to accept the US position even before the US decided what it was would present a different face to Italy's foreign policy. That this same government would take over the presidency of the European Union in the second half of the year gave poignancy to Italy's views on world affairs. However, trying to define Italy's position on the emerging world order reflects the opportunities (perhaps lost) and limitations presented by events in the last year. The war in Iraq provided Italian policy-makers with a series of difficult choices. Domestic preferences were clearly to pursue multi-lateral solutions through the UN, in concert with European partners. Not only would 
this placate anti-war sentiments at home, it would have helped consolidate the movement to create a single European voice on the world stage. Despite the government's insistence that it backed the United States, pressures within the coalition and popular opposition to the war all but ruled out military intervention. The result may have been one of the classic compromises endemic to Italian policy-making, but it proved to have its costs in relations with European partners. Perhaps the legacy of the post-war commitment to Europe did rein in the government; but the question of where Italy stands with respect to organizing the international order remains.

\section{Conclusion}

There have arisen a number of equilibrium points within the Italian polity. Some of these (such as the pro-European position) have developed throughout the post-World War II period, while others (for instance, concertation to reform the welfare state and labor markets) have emerged in the 1990s. These equilibriums have proved to be particularly resilient, even when faced with government initiatives determined to alter them. Indeed, the government's attempts in 2003 to introduce new parameters met with little success. This was not only because the pressures for change were often contradictory, but also because the forces of resistance manifested the crystallization of features that were not just national but also European. The integration of the national and European arenas tended to create a complex balance reflecting established interests, cognitive maps and world views, and the behavior and values of a plurality of actors and institutions. The events of 2003 demonstrate that the attempt to alter this balance requires more than just a change of domestic priorities.

If the above is a plausible interpretation, then two questions emerge. First, what is the degree of autonomy of the national level from the European level? Second, is it possible to alter the domestic polity without coherent European support? The two questions push us to investigate the importance of domestic politics within the context of a supranational Europe, or, more precisely, the capacity of Europe to influence domestic features that are increasingly Europeanized. The questions also invite us to reflect upon Italy's political and institutional transition. If Europe tends to protect equilibrium points that have already been achieved, and if these are not consistent with the needs to conclude the process of political and institutional change that have been underway in Italy since the early 1990s, then what should be the strategies pursued to complete the transition 
in conformity with the limitations and opportunities within Europe? Europe was one of the causes of the crisis in 1992-1996, when the Maastricht Treaty's strict convergence criteria shut off the public finance taps that had fed the "oligarchic pluralism" of the First Republic. ${ }^{11}$ Europe was then one of the factors that transformed the crisis during the period of transition after $1996 .^{12}$ It was the need to enter into the single currency that helped create an effective governing coalition led by Romano Prodi between 1996 and 1998. However, the transition has not been successfully concluded, if by this we mean the creation of a stable, coherent, bipolar political system, sustained by an institutional system characterized by cohesive, responsible governments. Could Europe be a factor that favors such a political and institutional outcome, even if it might mean putting into question some of the equilibria that emerged in the 1990s?

The past year in Italian politics and society provides interesting material for those interested in understanding the structural constraints placed on states by international, or regional, pressures and the space left for agency by national states and societies. ${ }^{13}$ The debates on European integration and globalization have been characterized by, on the one side, those who argue that the structures of global capitalism or European integration limit the space for national diversity and therefore autonomous state action, ${ }^{14}$ and, on the other side, those who maintain that states have retained the capacity for agency, so much so that the European Union or the international architecture is a creature of state actions. ${ }^{15}$ The Italian case reveals that perhaps the balance between structure and agency is much more delicate than presented in these two arguments. Europe has acted, at times, as an intervening factor in domestic politics as well as an independent variable. At the same time, developments within Italian politics and society have had an impact on the European level. Domestic factors serve to shape the decisions that might be made in the space for agency created by broader structural factors. States, however, are not simply passive participants responding to exogenous pressures. It is not just a question of them agreeing to pool sovereignty at the European level, which, in turn, sets a series of limits on what they can or cannot do. Rather, it is a politics of jumping scales in which political actors are constantly looking for room to maneuver between constraints and opportunities afforded to them by the availability of different sites and centers for politics. The national state remains the central political arena, but a number of currents run through it, from the local to the European and possibly beyond. We might say that there is nothing new in any of this, that national states have always been conditioned by a combination of endogenous and exogenous 
factors. Perhaps. But the intensity and the extension to more and more aspects of life seem to be new. Moreover, there is a growing awareness by the actors involved of the reciprocal relationship between the two sites and that this could be the basis for new opportunities in the same way as a constraint.

The chapters that follow illustrate the ways in which the parameters of Italian politics have adjusted to, transformed, and responded to both old and new pressures and dynamics. They trace a polity that has gone through a decade of tremendous change with its pillars still intact. Yet they also alert us to the challenges that lie ahead. As has been the case with previous volumes in this series, the chapters bring together leading experts in the field who reflect upon the most important events of the previous 12 months. They provide readers with a clear synthesis of the main events and try to place them within a broader understanding. In this way, they will illustrate to what extent there is still some agency at the national level and how it is constrained (or not) by exogenous, including sub-national, pressures.

- Translated by Lynn Mastellotto

\section{Notes}

The authors would like to thank Salvatore Vassallo for helpful comments on an earlier version of this essay.

1. As for Europe, the Single European Act (1986) introduced qualified majority voting within the Intergovernmental Council of Ministers. It was seen as an important turning point in the transformation of states (and therefore destined to deepen) in Western Europe.

2. Sergio Fabbrini, Tra pressioni e veti. Il cambiamento politico in Italia (RomaBari: Laterza, 2000).

3. Sergio Fabbrini, ed., L'europeizzazione dell'Italia. L'impatto dell'Unione Europea sulle istituzioni e le politiche italiane (Roma-Bari: Laterza, 2003).

4. See Michele Salvati, Il partito democratico. Alle origini di un'idea politica (Bologna: Il Mulino, 2003).

5. In an interview in La Repubblica on 11 December 2003, on the eve of the intergovernmental conference meeting in Brussels, Foreign Minister Franco Frattini reaffirmed that Italy could not "renounce its European ideal." His response to a question about the difficulties faced with Spanish Prime Minister Jose Maria Aznar was: "The difficulty Berlusconi and I faced was in 
always having to remind our partners that there was not a sum total of national interests. There is only one interest, the European."

6. Tobias Jones, The Dark Heart of Italy (London: Faber, 2003); Alexander Stille, "Italy: The Family Business," The New York Review of Books, 9 October 2003.

7. Interview with Guido Rossi in "L'Antitrust e la magistratura possono fermare la Gasparri," La Repubblica, 4 December 2003.

8. Paul Ginsborg, Berlusconi. Ambizioni patrimoniali di una democrazia mediatica (Torino: Einaudi, 2003).

9. Attempts to lay out this vision have been far from successful. See Ferdinando Adornato, La nuova strada. Occidente e libertà dopo il Novecento (Milano: Mondatori, 2003).

10. Marco Tarchi, L'Italia populista. Dal qualunquismo ai girotondi (Bologna: Il Mulino, 2003); Yves Meny and Yves Surel, eds., Democracies and the Populist Challenge (London: Palgrave, 2002).

11. See Sergio Fabbrini, "Political Change without Institutional Transformation: What Can We Learn from the Italian Crisis of the 1990s?" International Political Science Review 21, no. 2 (2000): 173-196.

12. Clearly, crisis and transition do not coincide, as the former does not necessarily generate the latter. See Fabbrini, Tra pressioni e veti, chap. 1.

13. John M. Hobson and M. Ramesh, "Globalisation Makes of States What States Make of It: Between Agency and Structure in the State/Globalisation Debate," New Political Economy 7, no. 1 (2002): 5-22.

14. Susan Strange, The Retreat of the State (Cambridge: Cambridge University Press, 1996).

15. Andrew Moravcsik, The Choice for Europe (Ithaca: Cornell University Press, 1998); Paul Hirst and Grahame Thompson, Globalization in Question: The International Economy and the Possibilities of Governance (Oxford: Polity Press, 1996). 
